\title{
The Concentration of the Salinity Indicators in the Water of the Bystrzyca River on the Area of Lublin City in Poland
}

\author{
Karolina Jóźwiakowska1 ${ }^{*}$, Natalia Brodowska², Mateusz Wójcik², Agnieszka Listosz ${ }^{3}$, \\ Agnieszka Micek³ ${ }^{3}$ Michał Marzec ${ }^{3}$, Patrycja Pochwatka ${ }^{3}$ \\ 1 Student, Faculty of Civil and Environmental Engineering, Warsaw University of Life Sciences, Nowoursynowska \\ 159, 02-787 Warsaw, Poland \\ 2 Student Science Association of Water and Wastewater Management, University of Life Sciences in Lublin, ul. \\ Leszczyńskiego 7, 20-069 Lublin, Poland \\ ${ }^{3}$ Department of Environmental Engineering and Geodesy, University of Life Sciences in Lublin, ul. \\ Leszczyńskiego 7, 20-069 Lublin, Poland \\ * Corresponding author's e-mail: karolina.jozwiakowska@tlen.pl
}

\begin{abstract}
The aim of the study was to assess the concentration of salinity indicators in the Bystrzyca River in the city of Lublin, located in south-eastern Poland. The studies on the quality of water from the river were carried out from November 2018 to June 2019, i.e. in winter and spring. The water samples for analysis were taken from 9 measurement points located on the river under bridges and at high traffic roads. In total, 8 series of analyses were carried out, during which 72 water samples from the Bystrzyca River were examined. The samples were analyzed in terms of: water temperature, $\mathrm{pH}$ value, conductivity as well as concentration of chlorides and sulfates. An increase in both the specific conductivity and chloride and sulfate concentrations was found in the water from the Bystrzyca River during the period of low air temperatures $\left(\leq 0^{\circ} \mathrm{C}\right)$, i.e. in December 2018 and January 2019. This may be a result of winter road maintenance procedures, i.e. by using salts for their defrosting. At the same time, an increase in the conductivity value and the concentration of chlorides and sulfates was observed with the course of the river, which indicates that the pollution generated in the city of Lublin has a negative impact on the water quality in the studied river. The salinity of the Bystrzyca River was greatly affected by the operation of the municipal wastewater treatment plant in Hajdów, especially by the use of coagulants: polyglycol chloride (PAX 18) and iron sulfate (PIX 113).
\end{abstract}

Keywords: $\mathrm{NaCl}$, chlorides, sulfates, specific conductivity, water, Bystrzyca River, Lublin city

\section{INTRODUCTION}

In Poland, due to its location in the zone of temperate, warm, transitional climate, snowfall occurs during winter. In order to prevent the icing of the streets and pavements, sodium chloride $(\mathrm{NaCl})$, calcium chloride $\left(\mathrm{CaCl}_{2}\right)$ and magnesium chloride $\left(\mathrm{MgCl}_{2}\right)$ are used, while $\mathrm{NaCl}$ represents $98 \%$ of total consumption [Masuria 2015]. The common use of salt is determined by its low price, ease of application and high effectiveness in temperatures down to $-9^{\circ} \mathrm{C}$. Thus, roadways and pavements quickly become black, which ensures safe movement of people and vehicles. However, it is widely known that salt causes corrosion of vehicles, roadside fences, posts or road signs. It destroys asphalt, pavements, shoes and causes degradation of roadside soils and vegetation. It is estimated that over $100 \mathrm{~kg}$ of salt is spilled on $1 \mathrm{~km}$ of the highway per year, which means that the amount of chlorides used may vary from 45 to $98 \mathrm{t} / \mathrm{km}^{2} /$ year [Trowbridge et al. 2010; Ramakrishna, Viraraghavan 2005]. Salty slush soaks into the soil and changes its chemical composition. This causes the plants growing along the roads to be unable to take up water from the soil in spring and wither away massively. Breś [2008] believes that the dying out of trees in urbanized 
areas is wrongly attributed to climate change, as this is rather the result of human activity. The most important causes of tree dying include soil chemical imbalance, deteriorating soil structure and porosity, lack or inadequate fertilization and tree stand devastation. Over the last 25 years, the number of trees growing along the streets in Warsaw has halved. Not only young plants but also older, larger trees are dying. On the other hand, Borowski and Pstrągowska [2011] demonstrated that high concentrations of salt on tree buds and shoots cause growth anomalies, deformation of the crown of older trees and growth inhibition of young ones. The salt that is sprinkled on the streets during winter infiltrates mostly to local rivers and lakes, where it is a threat to ecosystems. It leads, among others, to a decline in the biodiversity of aquatic organisms and particularly threatens amphibians and fish. The de-icing agents used in winter lead to salinity increasing not only in surface waters but also groundwater [Mazur 2015]. Therefore, the research on water salinity is very important and may indicate the scale of this problem under local conditions, and at the same time allow taking appropriate preventive actions.

The aim of this study was to assess the concentration of salinity indicators in the Bystrzyca River in the city of Lublin, located in south-eastern Poland.

\section{CHARACTERISTICS OF THE RESEARCH AREA}

Bystrzyca is one of rivers in the Lublin Upland and the largest river flowing through the city of Lublin (Figure 1). Its sources are located in the small village of Sulów, in Kraśnicki District, in the area of Urzędów Hills at an altitude of $227 \mathrm{~m}$ above sea level. After flowing $70.3 \mathrm{~km}$, Bystrzyca ends its run in Spiczyn, where it flows into the Wieprz River (a right-bank tributary of the Vistula River). The whole length of the river has five tributaries: right - Kosarzewka and Czerniejówka, and left - Krężniczaka, Czechówka and Ciemięga [Michalczyk 1997]. The Bystrzyca River flow below Lublin in the years 1990-2006 was on average $1.134 \mathrm{~m}^{3 \times} \mathrm{s}^{-1}$ [Michalczyk, Sposób 2009].

In 1974 as a result of the partition of the Bystrzyca valley with a 12-metre long front dam, the Lake Zemborzycki was created on the river, which belongs to quite shallow reservoirs. Its

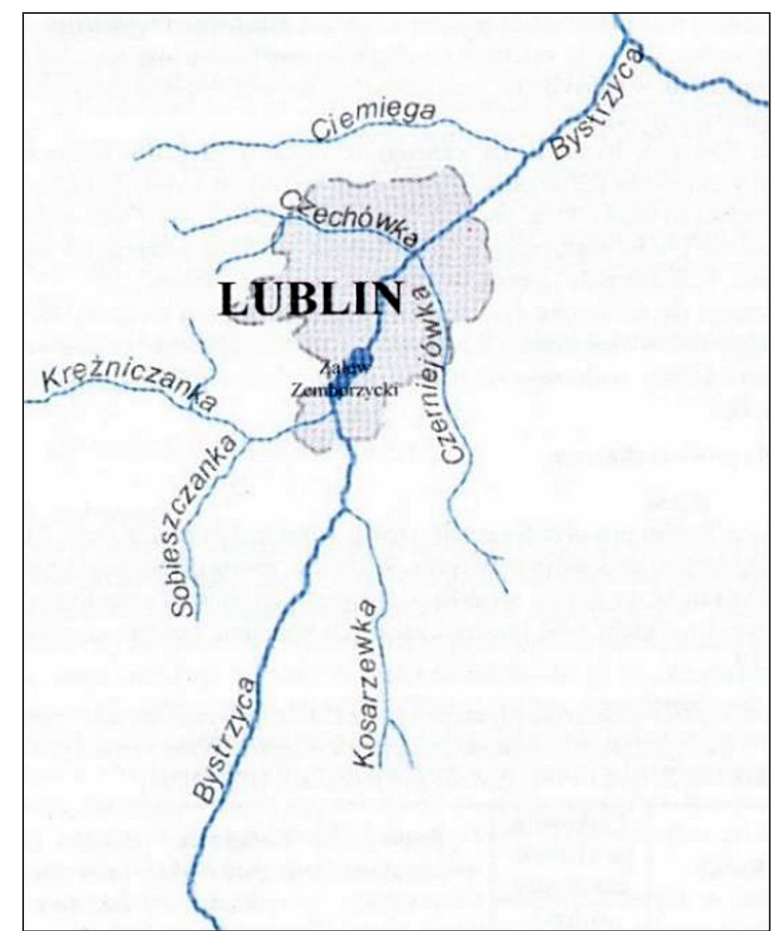

Figure 1. Surface waters on the Lublin area [Jóźwiakowska 2005]

average depth is $2.3 \mathrm{~m}$ and the maximum depth at the dam is about $4 \mathrm{~m}$. The main role of the reservoir is water retention, i.e. levelling of the flows of the Bystrzyca River by increasing low water flow and soothing high-water stages. It also has a recreational function, supplies water to the Wrotków power plant and powers the power plant, which produces electricity for the lighting of the Lake Zemborzycki [Radwan et al. 1999].

The Bystrzyca River basin has an area of $1315.5 \mathrm{~km}^{2}$ and, like the Vistula River basin, is largely used for the agricultural purposes. The largest area is occupied by agricultural land, there are few forests here. In the Bystrzyca valley, natural vegetation has been partially preserved: alder trees, water meadows, riverside rushes and meadows. Where the river stream is weak, duckweed grows in the water. Therefore, the river and its valley have quite rich fauna and flora [Zyśko et al. 1998; Kwiatkowska-Farbiś, Kucharczyk 1998].

The Polish Geological Institute, National Research Institute in Warsaw [2009] reported that the Bystrzyca River basin has been separated as a groundwater body and given no. 89. In the pore and crevice chalk limestones and quaternary sands of the Bystrzyca River basin, silica and carbonate type waters were found. Underground waters are characterized by high quality, although sometimes they require treatment due to 
the excessive iron and manganese content. The $\mathrm{pH}$ of these waters is 7.0-7.5 and the hardness is 300-500 mg $\mathrm{CaCO}_{3} \mathrm{dm}^{-3}$, which determines that they are considered as medium-hard waters. The groundwater of the Bystrzyca River basin is supplied by infiltration (percolation) of rainwater and by underground inflow.

The city of Lublin is inhabited by almost 340,000 people, and there are $479 \mathrm{~km}$ of district and commune roads with hard surface [Statistical Office in Lublin 2019]. However, in 2019 according to the data of the Lublin City Hall, over 264,000 cars were registered in the city. Such a large number of population, roads and cars have a negative impact on the water conditions and water quality of the Bystrzyca River [Michalczyk, Wilgat 2008; Borowska-Pakuła, Bober 2017]. Moreover, the Report on the State of the Environment of the Lublin Voivodeship in 2017 [2018] shows that below Lublin, the quality of the river's water in terms of the ecological and chemical condition is significantly deteriorating and is assessed as poor or even bad.

\section{SCOPE AND METHODS OF THE STUDY}

The research on the quality of water from the Bystrzyca River was carried out from November 2018 to June 2019, i.e. in winter and spring. The water samples for analysis were taken from 9 measurement points located on the river under bridges and by high traffic roads (Figure 2, Photo 1). The first point was located before the borders of the city of Lublin and the last one behind the Hajdów wastewater treatment plant, which treats municipal wastewater flowing out of the city of Lublin and surrounding towns. In total, 8 series of analyses were carried out, during which 72 samples of water from the Bystrzyca River were examined. The following physicochemical indicators were determined in the water samples:

- water temperature, $\mathrm{pH}$ value and specific conductivity were determined using ORION Star A329 Set multi-parameter meter by Thermo Scientific;

- the concentration of chlorides and sulfates was determined with the LF 300 photometer by Slandi.

The physical and chemical analyses of water samples were performed according to the commonly used methods [Hermanowicz et al. 1999].
On the basis of the results obtained, the minimum, maximum, average values and standard deviation were obtained. The results were compared with the limit values of the selected water quality indicators specified in the Regulation of the Minister of Maritime Economy and Inland Navigation [2019].

During the study, the changes in the concentration of salinity indices in the water of the Bystrzyca River in different months as well as along with the river course in Lublin were determined. The obtained results were compared to the average monthly air temperatures in the studied period from the meteorological station Lublin-Radawiec [Institute of Meteorology and Water Management - National Research Institute].

\section{RESULTS AND DISCUSSION}

Table 1 shows the minimum, maximum and average values of the examined pollution indicators as well as their standard deviations over the period considered (2018-2019).

Water temperature and $\mathbf{p H}$. The presented data show that the water of the Bystrzyca River had a weak alkaline $\mathrm{pH}$ which ranged from 7.25 to 8.21 . Similar values of water $\mathrm{pH}$ were recorded in the river during the years 2012-2014 by Grzywna et al. [2016]. The water temperature was measured at 9 sampling points along the course of the Bystrzyca River shown in the Figure 2. On the basis of the collected data, an average value of water temperature on the analyzed section of the Bystrzyca River was determined in every month examined in the study. The obtained values of water temperature were depicted in the Figure 3. The study shows that the water temperature in the Bystrzyca River is very well related to the air temperature, which is clearly visible in the Figure 3. During the study period, the air temperature ranged from $-3.4^{\circ} \mathrm{C}$ (in January) to $24.9^{\circ} \mathrm{C}$ (in June), and the water temperature in the river- from $6.8^{\circ} \mathrm{C}$ (in January) to $21.3^{\circ} \mathrm{C}$ (in June). It was also observed that the average water temperature increased along the river course - from $14.5^{\circ} \mathrm{C}$ at the point 1 to $15.2^{\circ} \mathrm{C}$ at the point 9 . The increase of the water temperature in the Bystrzyca River between the points 8 and 9 from 14.8 to $15.2^{\circ} \mathrm{C}$ is probably caused by the influence of warm wastewater flowing from the treatment plant in Hajdów. An increased temperature $\left(15.2^{\circ} \mathrm{C}\right)$ was also 


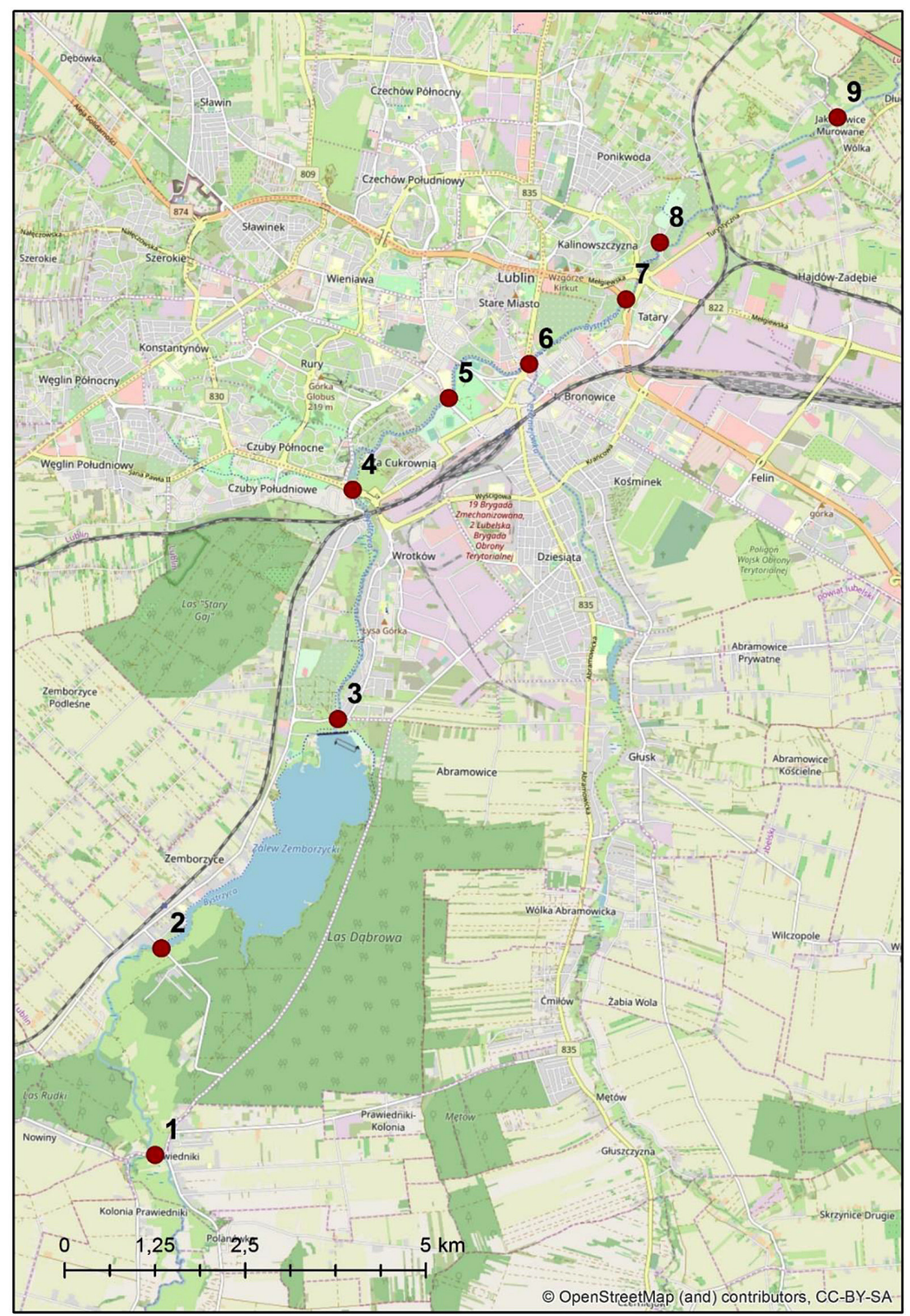

Figure 2. Location of water sampling points on the Bystrzyca River:

1 - ul. Prawiednicka, 2 - ul. Cienista, 3 - ul. Żeglarska, 4 - ul. Krochmalna, 5 - ul. Muzyczna,

6 - ul. Aleja Unii Lubelskiej, 7 - ul. Aleja Tysiąclecia, 8 - ul. Azaliowa, 9 - ul. Pliszczyńska

recorded in the river water at the point 3 (behind the Lake Zemborzycki), which indicates that this reservoir stores heat from the air and has an impact on the increasing water temperature in the studied river (Figure 4).

Specific conductivity. It was observed that the specific conductivity of water in the Bystrzyca River during the study period ranged from 482 to $713 \mu \mathrm{S} \times \mathrm{cm}^{-1}$ (Figure 5). The highest values were found in December $2018\left(713 \mu \mathrm{S} \times \mathrm{cm}^{-1}\right)$ and in January $2019\left(629 \mu \mathrm{S} \times \mathrm{cm}^{-1}\right)$, i.e. in the winter months when the air temperature was $\leq 0^{\circ} \mathrm{C}$. This shows that during this period, the values of electrolytic conductivity, which is positively correlated with salinity, indicate the use of salt for road maintenance.

The limit values for surface water quality classes (for highland carbonate streams with finegrained substrate on loess and loess-like rocks) were set in the Regulation of the Minister of Maritime Economy and Inland Navigation [2019]. According to this regulation, the specific conductivity of water in the Bystrzyca River during the winter was significantly higher than required for I $\left(\leq 374 \mu \mathrm{S} \times \mathrm{cm}^{-1}\right)$ or II $\left(\leq 550 \mu \mathrm{S} \times \mathrm{cm}^{-1}\right)$ surface water quality class. The lowest specific conductivity was found in the spring, i.e. from April to June $2019\left(482-489 \mu \mathrm{S} \times \mathrm{cm}^{-1}\right)$ (Figure 5). During this 

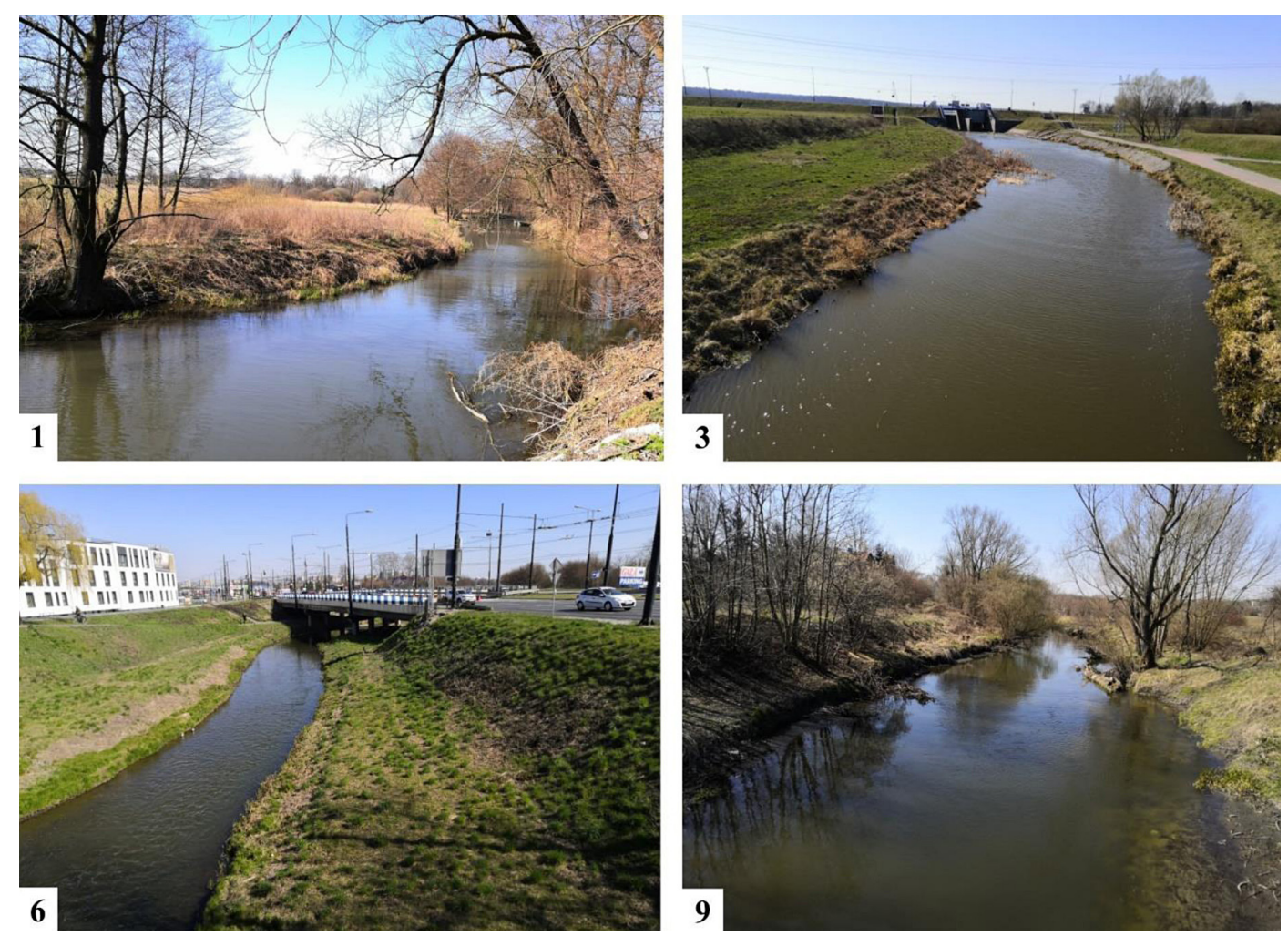

Photo 1. Selected water sampling points on the Bystrzyca River

period, the water from the studied river may be classified in the II quality class.

An increase in the specific conductivity along with the course of the river was observed - from 536 to $721 \mu \mathrm{S} \times \mathrm{cm}^{-1}$, which proves that the pollution generated in the city of Lublin has a negative impact on the water quality in the studied river (Figure 6). The highest value of specific conductivity $\left(721 \mu \mathrm{S} \times \mathrm{cm}^{-1}\right)$ was found at the point 9 , i.e. behind the wastewater treatment

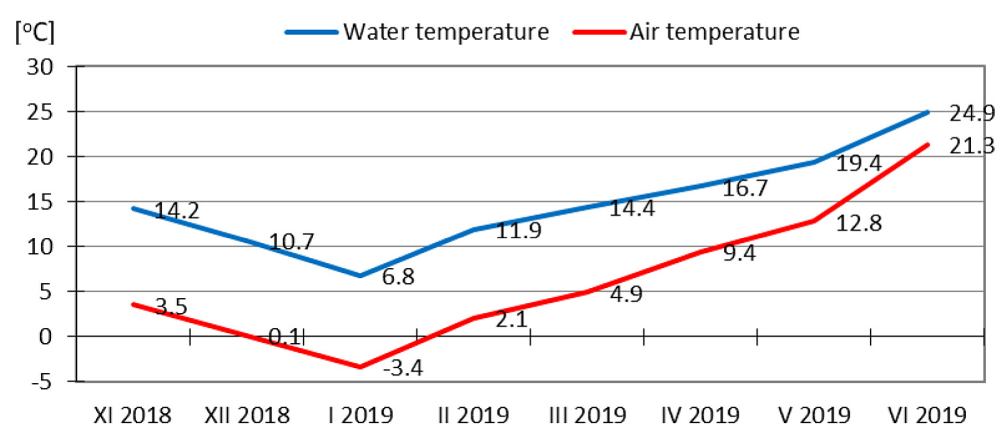

Figure 3. The air temperature in Lublin and the water temperature in the Bystrzyca River

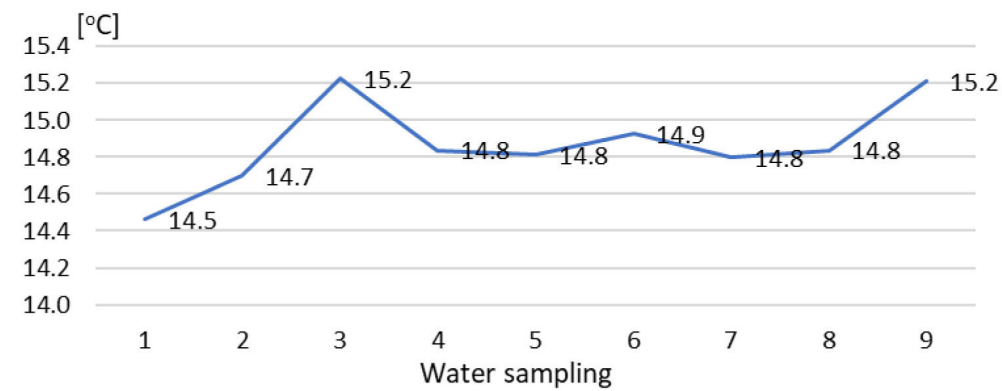

Figure 4. Changes of the average water temperature along the course of the Bystrzyca River 
Table 1. Concentrations of chosen pollutants indicators in the Bystrzyca River in 2018-2019

\begin{tabular}{|c|c|c|c|c|c|c|c|c|c|c|c|c|c|c|c|c|c|c|}
\hline \multirow{2}{*}{$\begin{array}{l}\text { No. of } \\
\text { samples }\end{array}$} & \multicolumn{2}{|c|}{$\mathrm{pH}$} & \multicolumn{4}{|c|}{$\begin{array}{c}\text { Temperature of water } \\
{\left[{ }^{\circ} \mathrm{C}\right]}\end{array}$} & \multicolumn{4}{|c|}{ Conductivity $\left[\mu \mathrm{S} \times \mathrm{cm}^{-1}\right]$} & \multicolumn{4}{|c|}{ Chlorides $\left[\mathrm{mg} \times \mathrm{dm}^{-3}\right]$} & \multicolumn{4}{|c|}{ Sulphates $\left[\mathrm{mg} \times \mathrm{dm}^{-3}\right]$} \\
\hline & $\min$ & $\max$ & $\min$ & ax & $\bar{x}$ & $\sigma$ & $\min$ & $\max$ & $\bar{x}$ & $\sigma$ & $\min$ & $\max$ & $\bar{x}$ & $\sigma$ & $\min$ & $\max$ & $\bar{x}$ & $\sigma$ \\
\hline 1 & 7.36 & 7.83 & 4.1 & 24.4 & 4.5 & 6.2 & 502 & 560 & 536 & 18 & 18 & 32 & 23 & 6 & 19 & 55 & 37 & 14 \\
\hline 2 & 7.50 & 7.90 & 5.8 & 24.2 & 14.7 & 5.8 & 529 & 604 & 557 & 23 & 2 & 34 & 25 & 10 & 39 & 81 & 59 & 13 \\
\hline 3 & 7.60 & 8.21 & 7.5 & 26.0 & 15.2 & 5.5 & 338 & 588 & 446 & 86 & 4 & 37 & 23 & $y$ & 42 & 139 & 66 & 30 \\
\hline 4 & 39 & .04 & 6.8 & 25.5 & 14.8 & 5.8 & 367 & 596 & 479 & 73 & 23 & 4 & 3 & 6 & 51 & 126 & 7 & 20 \\
\hline 5 & 7.27 & 7.89 & 6.5 & 2 & 14.8 & 5.8 & 40 & 764 & 51 & 12 & 25 & 4 & & 7 & 4 & 142 & 0 & 31 \\
\hline 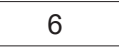 & 7.26 & 7.84 & 7.7 & 24.9 & 14.9 & 5.5 & 428 & 671 & 523 & 8 & 15 & 4 & 3 & 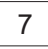 & 50 & 226 & 81 & 59 \\
\hline 7 & 7.30 & 7.72 & 7.0 & 24.6 & 14.8 & 5.5 & 490 & 863 & 579 & 129 & 19 & 53 & 39 & 12 & 70 & 92 & 8 & 8 \\
\hline 8 & 7.25 & 7.72 & 7.5 & 24.5 & 14.8 & 5.2 & 440 & 905 & 598 & 143 & 29 & 71 & 47 & 15 & 60 & 97 & 78 & 14 \\
\hline 9 & 7.33 & 7.70 & 8.0 & 24.7 & 15.2 & 5.2 & 580 & 1029 & 721 & 137 & 29 & 144 & 78 & 34 & 98 & 149 & 114 & 20 \\
\hline
\end{tabular}

plant in Hajdów, which proves that mainly this object affects a significant increase in the specific conductivity (Figure 6). Higher values of specific conductivity were found by Pytka et al. [2012] in the water of the Bochotniczanka River (589-746 $\mu \mathrm{S} \times \mathrm{cm}^{-1}$ ), which flows through the Nałęczów commune, located in the western part of the Lublin Voivodeship. Higher values of specific conductivity in Bochotniczanka were associated with disordered sewage management in the river basin. Even higher values of specific conductivity (459-838 $\mu \mathrm{S} \times \mathrm{cm}^{-1}$ ) were found in the water of the Biała River, which flows through Białystok and is a left-handed tributary of the Supraśl River [Wysocka-Czubaszek, Wojno 2014]. The authors found a negative impact of the city of Białystok on the quality of water in the Biała River and an increase in the value of specific conductivity with the course of the river. Significantly lower values of specific conductivity than in the Bystrzyca, Bochotniczanka or the Biała River were found in the surface waters intended for consumption, originating from the Wisłoka River - from $415 \mu \mathrm{S} \times \mathrm{cm}^{-1}$ (spring) to $486 \mu \mathrm{S} \times \mathrm{cm}^{-1}$ (winter) [Augustyn et al. 2012]. However, also in this case the highest conductivity values were recorded during winter.

Chlorides are the most important indicators of water salinity and are treated as an indicator of the anthropogenic water pollution in rural and urban areas [Macioszczyk, Jeż 1995]. According to Michalczyk and Rederowa [1993], the content of chlorides in the waters from the springs (in Sulów, Zakrzówek and Piotrowice), which supply the upper Bystrzyca, ranges from 4 to $11 \mathrm{mg} \times \mathrm{dm}^{-3}$. These values constitute the hydrogeochemical background of the Bystrzyca River and can be referred to when comparing the chloride concentrations along the river course or in different months of the year.

It was observed that the average concentration of chlorides in the water from the Bystrzyca River ranged from 24 to $44 \mathrm{mg} \times \mathrm{dm}^{-3}$ in the whole analyzed section in particular months of the year (Figure 7) and it was many times higher than that determined by Michalczyk and Rederowa [1993] in the upper course of the river.

The highest concentration of chlorides, just as specific conductivity, was found in Decem-

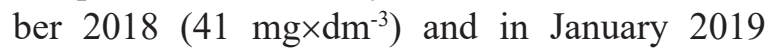
$\left(44 \mathrm{mg} \times \mathrm{dm}^{-3}\right)$, i.e. in the winter months when the

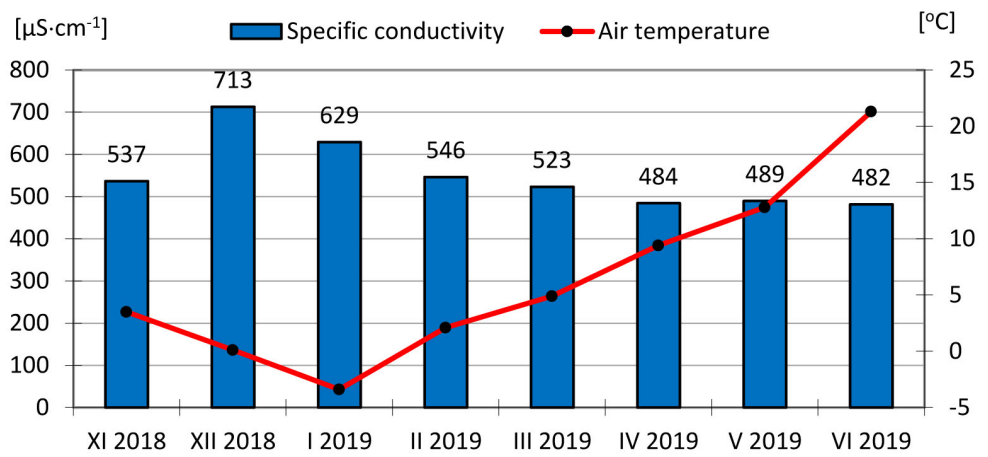

Figure 5. The air temperature in Lublin and the specific conductivity of the water in the Bystrzyca River 


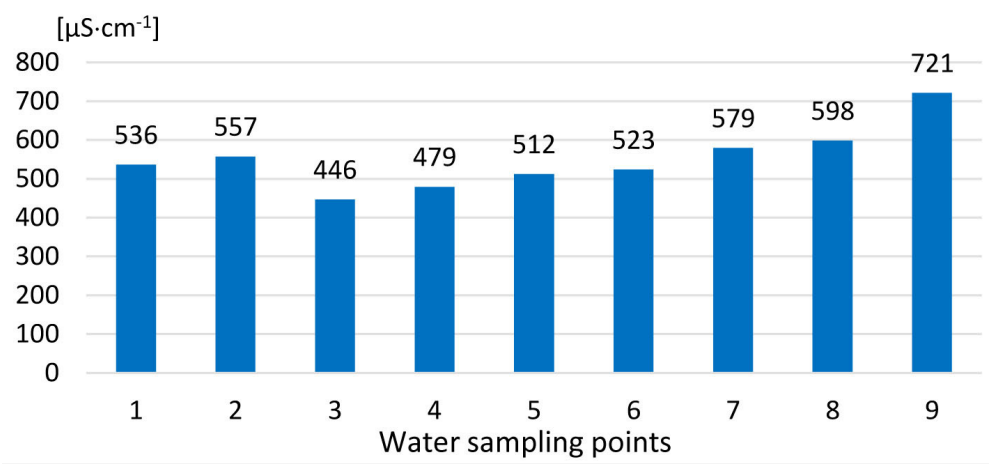

Figure 6. Changes of the average specific conductivity along with the course of the Bystrzyca River

air temperature was $\leq 0^{\circ} \mathrm{C}$. Therefore, it indicates that in the studied river the most chlorides in the water were found in the period when $\mathrm{NaCl}$ was most used for road maintenance. However, despite the increased concentration of chlorides in the winter period, the waters from the Bystrzyca River were in the first quality class in terms of their content throughout the whole study period $\left(\mathrm{Cl} \leq 51.9 \mathrm{mg} \times \mathrm{dm}^{-3}\right)$. The lowest concentration of chlorides in the water from the studied river was found in November $2018-24 \mathrm{mg} \times \mathrm{dm}^{-3}$ (Figure 7).

An increase in the chlorides concentration was noted along the course of the river - from 23 to $78 \mathrm{mg} \times \mathrm{dm}^{-3}$, which indicates that the pollution generated in the city of Lublin has a negative impact on the water quality and causes an increase in the salinity of the Bystrzyca River (Figure 8). The highest concentration of chlorides $\left(78 \mathrm{mg} \times \mathrm{dm}^{-3}\right)$ was found at the point 9 , i.e. behind the wastewater treatment plant in Hajdów, which proves that it is mainly this object that has a significant influence on the increase in the chlorides concentration (Figure 8, Table 1). According to the Regulation of the Minister of Maritime Economy and Inland Navigation [2019], the average concentration of chlorides in the water from the Bystrzyca River at the point 9 (behind the municipal treatment plant) was significantly higher than required for surface water quality class I $\left(\leq 51.9 \mathrm{mg} \times \mathrm{dm}^{-3}\right)$ or II $\left(\leq 68 \mathrm{mg} \times \mathrm{dm}^{-3}\right)$. Elevated concentration of chlorides in the water from the Bystrzyca River behind the treatment plant in Hajdów is probably related to the use of polyglycol chloride coagulant (PAX 18), which is used to reduce foaming and sheepskin formation in the activated sludge chamber [MPWiK in Lublin 2016].

Similar concentrations of chlorides, to those found in different months of the year in the Bystrzyca River (Figure 7), were observed in the water of the Biała River $\left(28.2-43.3 \mathrm{mg} \times \mathrm{dm}^{-3}\right)$ [Wysocka-Czubaszek, Wojno 2014]. The highest concentrations of chlorides were recorded during spring (March). The authors of the study explained this by the inflow to the river of waters from melting snow, which is heavily contaminated with salt used for street cleaning. Slightly lower chloride concentrations - in the range from 8.2 to $37.4 \mathrm{mg} \times \mathrm{dm}^{-3}$, were found by Augustine et al. [2012] in the surface waters intended for consumption, originating from the Wisłoka River. The authors stated that the highest chloride concentrations were recorded during the winter and summer months, and the smallest in autumn. They also indicated that the increased content of chlorides in winter is related to the use of $\mathrm{NaCl}$

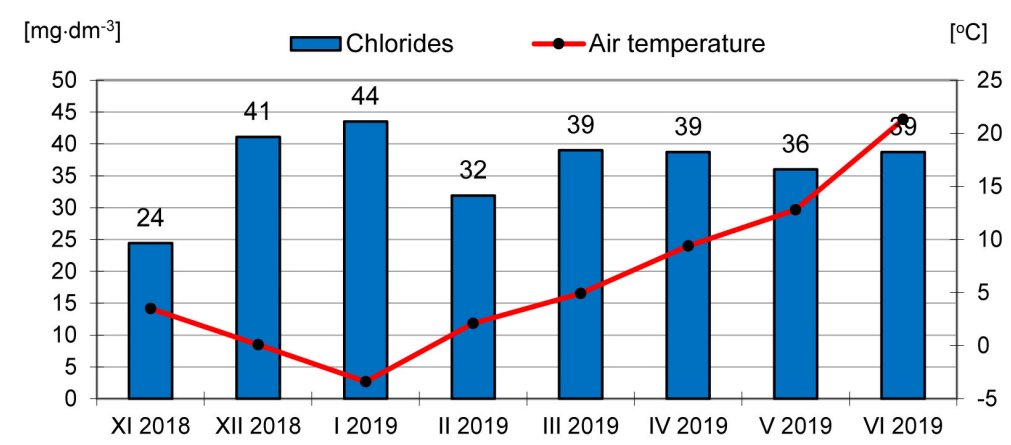

Figure 7. The air temperature in Lublin and the concentration of chlorides in the water of the Bystrzyca River 


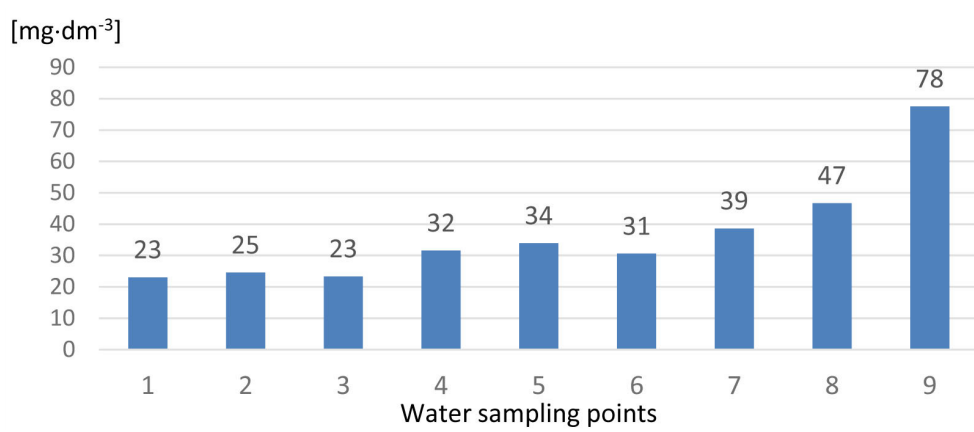

Figure 8. Changes of the average chlorides concentrations along the course of the Bystrzyca River

for defrosting roads and pavements in cities, while the lower one in the summer is due to low water levels in the river. Much higher concentrations of chlorides than in the Bystrzyca River were found in the water of the Bochotniczanka River $\left(27.0-86.5 \mathrm{mg} \times \mathrm{dm}^{-3}\right)$ [Pytka et al. 2013]. The authors stated that the direct impact on the deterioration of the quality of the Bochotniczanka River waters (including high chloride concentrations) is caused by the area-based pollution, especially surface runoff from eroded fields, as well as point-based pollution associated with disordered sewage management in the catchment area.

Sulfates. According to Michalczyk and Rederowa [1993], the content of sulfates in the waters from the springs (in Sulów, Zakrzówek and Piotrowice), which supply the upper Bystrzyca, varies from 5 to $12 \mathrm{mg} \times \mathrm{dm}^{-3}$. These values, as in the case of chlorides, may constitute the hydrogeochemical background of the Bystrica River water.

The average concentration of sulfates in the water from the Bystrzyca River, in the whole analyzed section in particular months of the year, ranged from 55 to $116 \mathrm{mg} \times \mathrm{dm}^{-3}$ (Figure 9) and was many times higher than that determined by Michalczyk and Rederowa [1993] in the upper part of the river. The highest concentration of sulfates in the water from the Bystrzyca River $\left(116 \mathrm{mg} \times \mathrm{dm}^{-3}\right)$ was found in June 2019, when low water levels were recorded [Michalczyk, Sposób 2009]. Elevated sulfate concentrations, similarly to specific conductivity and chlorides, were also observed in December $2018\left(77 \mathrm{mg} \times \mathrm{dm}^{-3}\right)$ and in January $2019\left(70 \mathrm{mg} \times \mathrm{dm}^{-3}\right)$, i.e. during the winter months when the air temperature was $\leq$ $0^{\circ} \mathrm{C}$. The lowest concentration of sulfates in the water from the studied river was found in May $2019-55 \mathrm{mg} \times \mathrm{dm}^{-3}$ (Figure 9).

On the basis of the conducted research, similarly to chlorides, an increase in the sulfate concentration was also recorded along the course of the river from 37 to $114 \mathrm{mg} \times \mathrm{dm}^{-3}$, which proves that the pollution generated in the city of Lublin has a negative impact on the water quality in the Bystrzyca River (Figure 10). Referring to the Regulation of the Minister of Maritime Economy and Inland Navigation [2019], it can be stated that the water in the Bystrzyca River in terms of the sulfate content in the points 1-4 meets the criteria specified for Class I $\left(\mathrm{SO}_{4} \leq 69.6 \mathrm{mg} \times \mathrm{dm}^{-3}\right)$ and in the points 5-8 for Class II surface water quality. The highest concentration of sulfates $\left(114 \mathrm{mg} \times \mathrm{dm}^{-3}\right)$ was found at the point 9 , i.e. behind the wastewater treatment plant in Hajdów, which proves that the plant causes a significant

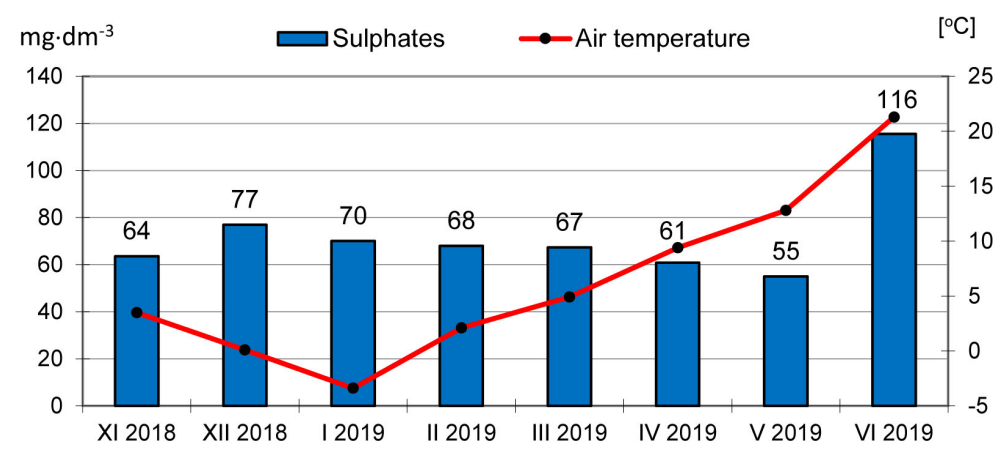

Figure 9. The air temperature in Lublin and the concentration of sulfates in the water of the Bystrzyca River 


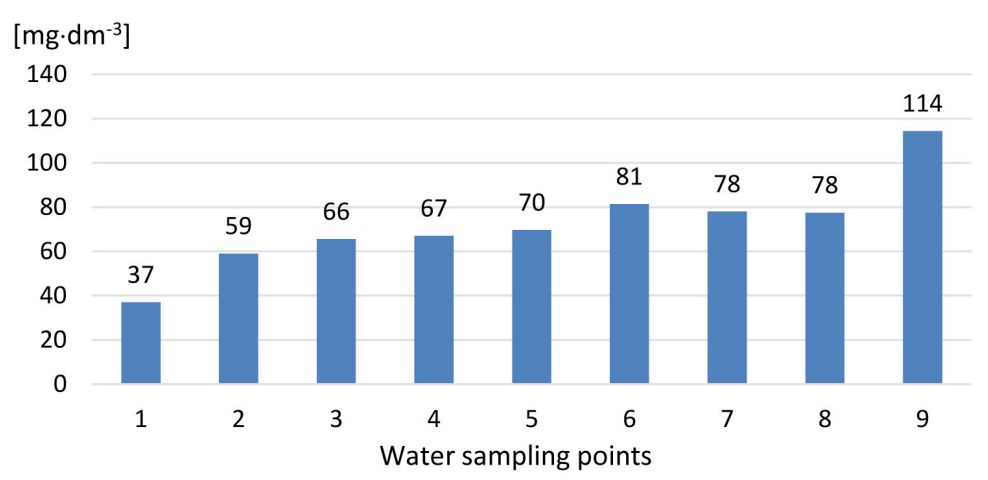

Figure 10. Changes of the average sulfates concentrations along the course of the Bystrzyca River

increase in the sulfate concentration (Figure 10, Table 1). According to the Regulation of the Minister of Maritime Economy and Inland Navigation [2019], the average sulfate concentration in the water from the Bystrzyca River at the point 9 (behind the municipal treatment plant) was higher than required for surface water quality class I $\left(\leq 69.6 \mathrm{mg} \times \mathrm{dm}^{-3}\right)$ or II $\left(\leq 111.4 \mathrm{mg} \times \mathrm{dm}^{-3}\right)$. Elevated sulfate concentration in the water from the Bystrzyca River beyond the treatment plant in Hajdów is probably related to the use of coagulant in the form of iron sulphate (PIX 113), which is used to condition the digested sludge to improve the effects of mechanical dewatering of sludge and also counteracts the precipitation of struvite (causing overgrowth of technological lines and hindering sludge dewatering) [MPWiK in Lublin 2016].

Lower concentrations of sulfates than in the water from the Bystrzyca River were found by Augustyniak et al. [2012] in the water from the Wisłoka River (on average $40.5 \mathrm{mg} \times \mathrm{dm}^{-3}$ ). Similar concentrations of sulfates to those recorded in the Bystrzyca River were found in the water of the Bochotniczanka River $\left(34.7-95.8 \mathrm{mg} \times \mathrm{dm}^{-3}\right)$, which flows through the Nałęczów Commune and is subject to anthropogenic influences as a result of disordered sewage management in the catchment area.

\section{CONCLUSIONS}

1. The Bystrzyca River is highly exposed to pollution originating from the city of Lublin, as evidenced by the increased values of the examined indicators in the water from the analyzed river.

2. The highest values of the salinity indicators of the Bystrzyca River water were found in
December 2018 and January 2019, i.e. during the months when the air temperature was $\leq 0^{\circ} \mathrm{C}$. This was probably due to the use of salt for defrosting road surfaces in the winter season.

3. An increase in the values of the specific conductivity and concentrations of chlorides and sulfates was observed along with the river course, which indicates an accumulated inflow of pollutants from various parts of the Lublin city, as a result of processes related to its functioning.

4. The salinity of the Bystrzyca River was greatly affected by the operation of the municipal wastewater treatment plant in Hajdów, especially by the use of coagulants: polyglycol chloride (PAX 18) and iron sulfate (PIX 113) in the wastewater treatment process.

\section{Acknowledgements}

Publication is the result of participation in the project ,Organization of the $9^{\text {th }}$ International Scientific and Technical Conference entitled Environmental Engineering, Photogrammetry, Geoinformatics - Modern Technologies and Development Perspectives" funded by the Polish National Agency for Academic Exchange under the International Academic Partnerships Programme.

\section{REFERENCES}

1. Augustyn Ł., Kaniuczak J., Stanek-Tarkowska J. 2012. Selected physicochemical and chemical properties of surface water of Wisloka for consumption. Inżynieria Ekologiczna 28, 7-19 (in Polish).

2. Borowski J., Pstrągowska M. 2010. Effect of street conditions, including saline aerosol, on growth of the Small-leaved limes. Rocznik Polskiego Towarzystwa Dendrologicznego 58, 15-24. 
3. Breś W. 2008. Anthropopressure factors causing trees to die off in urban landscape. Nauka Przyroda Technologie 2 (4), 1-8 (in Polish).

4. Grzywna A., Jóźwiakowski K., Gizińska-Górna M., Marzec M., Mazur A., Obroślak R. 2016. Analysis of ecological status of surface waters in the Bystrzyca river in Lublin. Journal of Ecological Engineering 17 (5), 203-207.

5. Hermanowicz W., Dojlido W., Dożańska W., Koziorowski B., Zerbe J. 1999. Physicochemical study of water and wastewater. Arkady. Warszawa, p. 556 (in Polish).

6. Institute of Meteorology and Water Management - National Research Institute. Average monthly air temperatures from the Lublin-Radawiec meteorological station, 1951-2020. https://meteomodel. $\mathrm{pl} /$ dane/srednie-miesieczne/?imgwid $=351220495$ \& par=tm (in Polish).

7. Jóźwiakowska I. 2005. Water and wastewater management in Lublin. Wyd. Lubelska Fundacja Ochrony Środowiska Naturalnego. Regionalne Centrum Edukacji Ekologicznej, p. 32 (in Polish).

8. Kwiatkowska-Fabryś M., Kucharczyk M. 1998. Water, meadow, turf and ruderal plant communities of the city of Lublin. In: Chmielewski T.J. (Ed.). Nature inventory of the city of Lublin. Urząd Miasta Lublin, Lublin, 53-59 (in Polish).

9. Macioszczyk A., Jeż L. 1995. Chlorides as a sensitive indicator of anthropogenic groundwater pollution. Materials of the VI Symposium "Contemporary Hydrogeology Problems”, Kraków-Krynica (in Polish).

10. Mazur N. 2015. Impacts of road deicing salt on natural environment. Inżynieria i Ochrona Środowiska 18 (4), 449-458 (in Polish).

11. Michalczyk Z., Rederowa E. 1993. Sources in the Bystrzyca river basin. In: Michalczyk Z. (ed.), Sources of the western part of the Lublin Upland. Wyd. UMCS, Lublin, 93-157 (in Polish).

12. Michalczyk Z. (red.) 1997. The strategy of water use and protection in the Bystrzyca river basin. Wydaw. UMCS, Lublin, 1-192 (in Polish).

13. Michalczyk Z., Sposób J. 2009. The influence of an urbanized area on the regime of river discharges in the Lublin agglomeration. Geographia Polonica 82 (1), 89-98.

14. Michalczyk Z., Wilgat T. 2008. Water. In: Uziak S., Turski R. (ed.). The natural environment of the Lublin region. Lubelskie Towarzystwo Naukowe, 113-209 (in Polish).

15. MPWiK w Lublinie. 2016. Environmental declaration. Listopad 2016. Miejskie Przedsiębiorstwo Wodociągów i Kanalizacji w Lublinie Sp. z o.o. (in Polish).
16. Państwowy Instytutu Geologicznego, Państwowy Instytut Badawczy w Warszawie 2009. Tasks of the State Hydrogeological Service in 2009, Task No. 28: Geological and hydrogeological characteristics of verified JCWPd, p. 28 (in Polish).

17. Pytka A., Jóźwiakowski K., Marzec M., Gizińska M., Sosnowska B. 2013. Impact assessment of anthropogenic pollution on water quality of Bochotniczanka river. Infrastruktura i Ekologia Terenów Wiejskich 3 (2), 15-29 (in Polish).

18. Radwan S. Paleolog A, Stępień B, Bojar W. 1999. Ecological condition of the Zemborzycki reservoir near Lublin - changes over time. Materials from the scientific conference on "Biological aspects of dam reservoir functioning, Lublin 9-12 September 1999 (in Polish).

19. Ramakrishna D.M., Viraraghavan T. 2005. Environmental impact of chemical deicers - a review. Water Air Soil Pollut 166, 49-63.

20. Statistical Office in Lublin 2019. City of Lublin. Statistical local government vademecum (in Polish).

21. Regulation of the Minister of Maritime Economy and Inland Navigation of 11 October 2019 on the classification of ecological status, ecological potential and chemical status as well as the method of classifying the status of surface water bodies as well as environmental quality standards for priority substances. Dz. U. z dnia 7 listopada 2019 r., poz. 2149, Warszawa (in Polish).

22. Report on the state of the environment of the Lublin Voivodeship in 2017. 2018. Inspekcja Ochrony Środowiska, Wojewódzki Inspektorat Ochrony Środowiska w Lublinie. Biblioteka Monitoringu Środowiska, Lublin, p. 211 (in Polish).

23. Trowbridge P. R., Kahl J.S., Sassa D.A., Heath D.L., Walsh E.M. 2010. Relating road salt to exceedances of the water quality standard for chloride in New Hampshire streams. Environm. Sc. Techno., 44 (13) 4903-4909.

24. Wojciechowska-Bartnik J., Jałtoszuk O. 2018. The importance of the Bystrzyca valley in the spatial structure of Lublin in terms of historical, natural and functional aspects and the possibilities of its development. Annales UMCS, Vol. LXXIII, Sectio B, 195-211 (in Polish).

25. Wysocka-Czubaszek A., Wojno W. 2012. Seasonal changes of water chemistry in a small river in an urban catchment. Scientific Review - Engineering and Environmental Sciences 63, 64-76 (in Polish).

26. Zyśko T., Jamróz J., Kwiatkowska-Fabryś M., Kucharczyk M. 1998. Lublin's forests. In: Chmielewski T.J. (Ed.). Nature inventory of the city of Lublin. Urząd Miasta Lublin, Lublin, 36-53 (in Polish). 